\title{
HEALING THE SICK POOR: SOCIAL POLICY AND DISABILITY IN NORWICH 1550-1640
}

\author{
by
}

\author{
MARGARET PELLING*
}

In the history of social policy in Britain, state medicine is not seen as the natural state of affairs. Rather, it seems that medical services have been provided by the state in the twentieth century only after a process of painful evolution in the nineteenth, which even now is not complete. Only the inexorable effects of industrialization were able to force upon policy-makers an awareness of the social and economic cost of ill health and early death. Before this point of crisis, health care was primarily delivered by voluntary agencies. Medical poor relief began to be organized on a parochial basis in the eighteenth century, but this remained a meagre and makeshift version of what was evolving on the voluntary level. The workings of private philanthropy continued to be the main support of the less fortunate members of society. This perspective has been supported by assumptions about the growth of medicine as a profession. Medical historians, although increasingly aware of the sophistication of public medical provision on the continent, incline to the view that medical poor relief began in England towards the end of the seventeenth century because they also assume that the medical profession was insufficiently developed before this date. If the poor were treated at all previously, it was by barbers and old women. It is assumed that authorities of the earlier period either had no faith in the effectiveness of medical practitioners, a view which leads inevitably to anachronism, or that they considered them too few or too expensive to have any relevance to the poor. ${ }^{1}$

This set of assumptions could be attacked in a number of different ways. It has been remarked that, with respect to the early modern period, attitudes to social policy are better known than their application. ${ }^{2}$ An intensive study of the scattered

\footnotetext{
* Margaret Pelling, Wellcome Unit for the History of Medicine, 45-47 Banbury Road, Oxford OX2 6PE.

${ }^{1}$ Typical of prevailing assumptions is G. W. Oxley, Poor relief in England and Wales 1601-1834, Newton Abbot, David \& Charles, 1974. Still to be recommended are E. M. Leonard, The early history of English poor relief, Cambridge University Press, 1900; H. Levy, 'The economic history of sickness and medical benefit before the Puritan Revolution', Econ. Hist. Rev., 1943, 13: 42-57; F. G. Emmison, 'Poor relief accounts for two rural parishes in Bedfordshire, 1563-1598', ibid., 1931-2, 111: 102-116; idem, 'The relief of the poor at Eaton Socon, 1706-1834. . ', Publ. Beds. Hist. Rec. Soc., 1933, 15: 1-98; idem, 'The care of the poor in Elizabethan Essex. Recently discovered records', Essex Review, 1953, 62: 7-28. See also J. Webb (editor), Poor relief in Elizabethan Ipswich, Suff. Rec. Soc., vol. 9, 1966; P. A. Slack, 'Some aspects of epidemics in England 1485-1640', Oxford University DPhil. dissertation, 1972; idem, Poverty in early Stuart Salisbury, Wiltshire Rec. Soc., vol. 32, 1976; C. Webster, The great instauration: science, medicine and reform 1626-1660, London, Duckworth, 1975, Section IV; M. Pelling and C. Webster, 'Medical practitioners', in C. Webster (editor), Health, medicine and mortality in the sixteenth century, Cambridge University Press, 1979, esp. pp. 217-223.
} 


\section{Margaret Pelling}

evidence relating to the practices of one early modern town, Norwich, has shown that attention to applications can be unexpectedly rewarding. This evidence shows considerable local authority provision of medical services, existing independently of any major institutionalization and calling on a remarkably high proportion of the numerous medical practitioners active in the town. Norwich can be shown to have had a well-developed awareness of the social and economic importance of illness, and to have been prepared to invest not only in prevention but also in medical intervention. Although Norwich seems to have acted primarily to avert public danger and public expense, it could be suggested that the town's authorities were showing a collective alertness to the manifestations of disease which paralleled the individual's concern for health matters at this time. ${ }^{3} \mathrm{~A}$ high incidence of disease does not seem to have bred indifference at any level.

Much writing on the subject of poor relief in general in the early modern period has been concerned with definitions of the poor connected with the principles of catholicism, humanism, or protestantism. Stress has been placed on the fragmentation of "God's poor"-a holistic attitude supposedly characteristic of the pre-Reformation period-into the deserving and the undeserving, the able and the impotent. It has often been stated that sixteenth-century authorities, in their obsession with putting down vagrancy, were slow to evolve even relatively crude categories of "approved" poor. More recently, Paul Slack has suggested in relation to Salisbury that these binary distinctions could become modified, as well as sharpened, as a result of economic crisis leading to massive unemployment. ${ }^{4}$ The Norwich evidence confirms that towns of this period were capable of more discrimination as to the causes of poverty than these categories imply. I should like to suggest further that this insight, although made more evident by economic crisis, was also based on traditional practices and the adaptation of existing institutions.

A strong faith in the results that could be expected from a system of medical intervention is not unknown as a feature of some ambitious plans for improving the condition of the poor in the early modern period. During the Puritan Revolution, the economic reformer Henry Robinson, for example, recommended that physicians and surgeons should be appointed in every county at the public expense, to visit and administer on request, for no consideration other than that allowed them by the state. Similar ideas had also been put forward in the sixteenth century by utopian writers and humanist reformers. Henry Brinklow, in the context of the use of the profits of the Dissolution, had advocated physicians, surgeons, and houses for the sick in every city, town, and hundred. The practitioners, again, were to live on their stipends alone, on pain of mutilation. ${ }^{5}$ The religious reformer William Marshall has

\footnotetext{
${ }^{2} \mathrm{P}$. Slack, 'Social policy and the constraints of government 1547-58', in J. Loach and R. Tittler (editors), The mid-Tudor polity c. 1540-1560, London and Basingstoke, Macmillan, 1980, p. 107.

${ }^{3} \mathrm{C}$. Webster, 'Medicine as social history: changing ideas on doctors and patients in the age of Shakespeare', in L. G. Stevenson (editor), A celebration of medical history, Baltimore, Md., Johns Hopkins University Press, 1982, pp. 115-116.

'P. Slack, 'Poverty and politics in Salisbury 1597-1666', in P. Clark and P. Slack (editors), Crisis and order in English towns 1500-1700, London, Routledge \& Kegan Paul, 1972, pp.164-203.

${ }^{5}$ Webster (1975), op. cit., note 1 above, p. 291; see also the schemes of "Dr Turnbull", ibid., p. 300. Henry Brinklow, Complaynt of Roderyck Mors [c. 1542], ed. by J. M. Cowper, Early English Text Soc., Extra Ser. vol. 22, 1874, p. 52;
} 


\section{Healing the sick poor}

been credited with a poor law scheme which had a great influence on the poor law legislation of 1536. This scheme included the following provisions:

It is also enacted by thauctorite aforeseid that if any such vacabunde and idle persones be sicke, which of likeliod myght well labour if they were hoole, that then theseid deputies shall assigne certeyn Phisicians and Surgeons to loke vnto and remedie ther diseases; And that thesame Phisicians and Surgeons shalbe paied for ther labour and paynes in and about the curyng and helpyng of the sicke and sore vacabundes and idle persones, as is aboueseid, of theseid moneye and of thother charite of the people; And when such sicke and sore persones ben cured and heled, then they to be put to labour in theseid workes vnder the paynes before expressed.

The possible application of such schemes has hardly been considered by historians. Marshall's scheme is regarded as beyond the capacity of Tudor or even of later administrations. ${ }^{6}$ Nonetheless, the system in use in Norwich can be shown to have had some of the essential characteristics of Marshall's plan. The most important of these was the attention paid to those who "myght well labour if they were hoole". It is significant that those too old, weak, or sick to work again were dealt with separately in a later part of Marshall's scheme. Similarly, this paper will not be particularly concerned with almshouses or the impotent poor. Norwich's approach to the sick poor lacked the broader vision of Robinson's proposals, in particular the statesalaried element, but was suited to the climate of the time. Tempering this outlook was a well-developed conviction of the role of sickness in creating poverty. Marshall himself, writing in the 1530s, placed sickness first among the "casualties" affecting people who were poor through no fault of their own.

\section{I}

Norwich is famous for its initiatives in respect of poor relief and regulation, particularly in the 1570 s. $^{7}$ Marshall's national scheme, which predated the Dissolution, depended heavily on voluntary almsgiving; by contrast, Norwich introduced a compulsory poor rate only fourteen years later, in 1549, and was apparently the first provincial town to enforce such a measure. Some of its medical poor relief practices seem to be associated with its major poor scheme of the 1570s; nonetheless, in many respects these practices reached their greatest development some decades later, in the early seventeenth century. An apparent decline in the 1630s, particularly in the institutional side of the system, raises questions connected with poor relief policy in general in the Laudian period, but the evidence is insufficient for clear answers to these questions. More striking is the continuity of Norwich's ad hoc provision of medical care, which in terms of its funding was centralized and largely independent of the poor rate, and which seems to have persisted to some degree into the eighteenth century.

The operation of Norwich's system is best dealt with by first considering sickness as an aspect of poor relief problems and practices in the town before 1600 . I will then go on to examine the role of individual practitioners employed to treat the poor. Later

${ }^{6} \mathrm{G}$. R. Elton, 'An early Tudor poor law', Econ. Hist. Rev., 1953, 6: 143, 154, 140.

${ }^{7}$ See Leonard, op. cit. note 1 above, pp. 101-107; J. F. Pound, 'An Elizabethan census of the poor: the treatment of vagrancy in Norwich, 1570-1580', Univ. Birm. hist. J., 1961-2, 8: 135-162, esp. p.136. 


\section{Margaret Pelling}

sections will establish that, while no major part was played by any single institution, short-term institutional care was provided for the sick by the keepers of lazarhouses, the importance of which increased after 1600 .

The scheme of the 1570s involved custodial care, discipline, training, some education, and work for all ages according to their capacities. It was intended to make the poor entirely self-supporting or even profitable. Less attention has been paid to the fact that it also laid considerable stress on the prevention of disease. The lives of the poor were so ill-regulated, according to Norwich's interpretation of the rules of health, that if allowed to beg they suffered from excess as well as privation. Indiscriminate private philanthropy had led directly to ill health. And:

So cared they not for apparel though the cold struck so deep into them, that what with diseases and want of shifting their flesh was eaten with vermin and corrupt diseases grew on them so fast and so grievously that they were past remedy ... . for want of exercise of body and shift of apparel both the old and the young fall (by extreme poverty) into such incurable diseases and filthiness of body as one so corrupteth another that the charge to heal them is very great. ${ }^{8}$

Children living such lives became physically disqualified from being apprenticed. Prosperous parishioners obliged to take on a parish apprentice could reject the child on such grounds as its lameness, sickliness, or scald head; one such apprentice had a "scald and scurvy head which is infectious", another developed a "thistell upon his body and limes". As always at this period, the perceived link between behaviour and disease was very close. In one incident, an apprentice who ran away, was recorded as contracting diseases from sleeping in ditches; in a more extreme case of absconding involving theft, the apprentice's legs rotted off. ${ }^{9}$ The emphasis on clothing complements the dominance, evident in the records, of diseases showing themselves on exposed parts of the body, and helps to explain the considerable expenditure on clothing for the poor at this time.

The stress in the 1570s on prevention stemmed directly from the fact that the community was already providing substantial sums for the cure of disease. It was claimed at the end of the first year of operation of the Norwich poor scheme that supervising the poor and putting them on work had saved the cost of an annual burden, arising directly from cases of disease, of 200 "licences to collect", each licence involving at least twenty-six shillings, giving a total of over $£ 260$ per annum. ${ }^{10}$ These licences were specifically for raising money to finance expensive cures. Different forms of licences to collect, also called protections, were widely used in the sixteenth century to sanction traditional although increasingly suspected forms of begging, for example, the financing of their studies by poor university students, and the support of poor parishes or hospitals. ${ }^{11}$ At this time, they were issued by all levels

\footnotetext{
${ }^{8}$ Quoted from R. H.Tawney and E. E. Power (editors), Tudor economic documents, 3 vols., London, Longmans, 1953, vol. 2, pp. 317-318.

'Ibid.; D. E. H. James, Norfolk quarter sessions order book 1650-1657, Norf. Rec. Soc., vol. 26, 1955, pp.19, 39, 46, 47, 50, 84-85. For an earlier reference to sickness and parish apprenticeship, see 27 Henry VIII c.25.

${ }^{10}$ Quoted in Tawney and Power, op. cit., note 8 above, vol. 2, p.318.

${ }^{11}$ T. N. Brushfield, 'Devonshire briefs', Trans. Devons. etc. Assoc., 1895, 27: 311-357; 1896, 28: 606-711. W. A. Bewes, Church briefs; or royal warrants for collections for charitable objects, London, A \& C. Black, 1896. B. Clarke, 'Norfolk licences to beg: an unpublished collection', Norfolk Archaeology, 1970-3, 35: 327-334.
} 


\section{Healing the sick poor}

of authority, ecclesiastical and lay, and were taken from door to door, as well as from church to church. The text of the licence to gather in respect of sickness could include the testimony of a practitioner as to the necessity, feasibility, and cost of treatment, as well as a statement of the licensee's inability to raise the cost by his own efforts. Parish officials and the clergy were required to assist or at least not to hinder the licensee both in the collection and in his travelling either to seek treatment or to contact friends and relatives who might be able to help.

Norwich's hope of permanently superseding this type of licensed begging by the systematic preventive measures of its poor scheme was not fulfilled, although the volume of licensing may have been greatly reduced as a matter of policy. Nine such licences to collect for medical reasons were recorded as being issued by Norwich's mayor's court during the lean years $1596-8$, for periods of six weeks to three months, to persons unable to pay for treatment of such conditions as fistula, falling sickness, and broken legs. In respect of a case of stone, which could involve very high fees, the licence was renewed for a second period of three months. The use of these licences may explain the mobility of some patients and suggests a less restricted capacity in the market to pay high fees, as well as a broader class range of recipients of medical "poor relief". Licences were probably most used where they have been least noticed, that is, at the local level as dictated by the municipal authority. In such cases, the area of collection was restricted to the city boundaries or even limited to a particular ward. These licences also allowed the poor of the suburbs some access to the greater affluence of the town. Similar licences were still being used in respect of costly medical services in the late seventeenth century. In thus linking over time the pre-Reformation stress on almsgiving with the voluntaryist principles evident in the early eighteenth-century founding of the infirmaries, they are a reminder of the persistence of the connexions between medicine and ecclesiastical authority.$^{12}$ It is equally characteristic of the 1570 s that Norwich should have wished to supersede these licences. They may have been revived in the $1590 \mathrm{~s}$ as an emergency measure for more expensive cases, with the hope that their use could be avoided in future by directly employing bonesetters, lithotomists, and lazarhouse keepers.

The use of licences was not systematic and depended on individual application and individual generosity. That Norwich saw sickness as a vital element in any thorough effort connected with the poor is shown by the inclusion of details of state of health in the famous and unusually comprehensive "Census of the Poor" conducted at the outset of the poor scheme in 1570 . The census thus provides an opportunity of estimating morbidity which may be unique. ${ }^{13} \mathrm{~A}$ total of 2,359 men, women, and children were described in the census, being perhaps a quarter of the whole nativeborn population. ${ }^{14}$ Although the preamble to the census complained of vagrancy, the

\footnotetext{
${ }^{12}$ Norfolk Record Office [NRO], press D, case 16, shelf a, Mayor's Court Proceedings no. 13, pp. 106, $115,119,123,145,167,175,177,182$. For late seventeenth-century examples see $\mathrm{C}$. Williams, 'Extracts from the court rolls [sic] of ... Norwich relating chiefly to ... stone', Lancet, 1898, ii: 1181-1182.

${ }^{13}$ I intend to compare the Norwich estimate with others in a future paper. The complete version of the census, discovered by Pound in 1962, is reprinted in J. F. Pound (editor), The Norwich census of the poor 1570, Norf. Rec. Soc., vol. 40, 1971. Pound's introduction does not analyse morbidity.

${ }^{14} \mathrm{~W}$. Hudson and J. C. Tingey (editors), The records of the city of Norwich, 2 vols., Norwich and London, Jarrold \& Son for the Corporation, 1906-10, vol. 2, pp. cxxvii-cxxviii.
} 


\section{Margaret Pelling}

poor counted in the census, as in earlier continental instances, were not vagrants, but resident poor. Some were in their own houses; a majority were the tenants of prominent citizens or aldermen. About nine per cent of the adult poor (that is, over the age of sixteen), were described at that time as being in some way sick or disabled, although many did some work nonetheless. A further $1 \frac{1}{2}$ per cent of adults, all of them aged, were described simply as past work. These included many of the very few women who did no work. ${ }^{15}$ Rather more women than men were affected by sickness or disablement, but this was merely in proportion to the greater number of poor women overall (i.e. 860:525). A few ill children were mentioned. Among adults, the greatest numbers suffering illness or defect combined with poverty were between the ages of forty-one and sixty; in early adulthood, sickness was more noticed among men, but sick women were more numerous in old age. Clearly, in adulthood, sickness was a function of increasing, rather than old age, being a problem from the age of forty onwards.

The census population is artificial in lacking the major part of the age group 15-24, which has been estimated as 19.77 per cent of the English population in 1571, as compared with only 5.72 per cent of the census population. The extent to which sickness affected the middle-aged becomes more striking when account is taken of the unsurprising tendency of a population selected for poverty to include many old people, who might have been expected to dominate any picture of morbidity. Those aged sixty and over formed an estimated 7.32 per cent of the total English population of 1571 , compared with twice that percentage ( 14.83 per cent) of the census population (or 13.01 per cent if the "missing" adolescents are added). ${ }^{16}$

About a third of the sick poor of the census were simply described as sick, sickly, or very sick. Others were called weak, diseased, bed-ridden, lame, crooked, or suffering from stone, gout, dumbness, deafness, broken legs, diseases of the mouth, broken ribs, thigfola (? fistula), or were one-legged or one-handed. One woman aged thirty-six lay "in the pokes [pox] as she sayth by Tomson"; three men and women were "somewhat lunatic" or "beside themselves" and unable to work, though all three were apparently living independently. One sick woman aged sixty (with a husband aged thirty-seven) nonetheless "spins white warp and teaches youth". A lame but able woman in her fifties did not work but had alms of $1 d$. a week, distilled aqua vitae, and "lived off her friends". Of ten blind or "almost" blind men and women, one still worked as a baker, and a woman of eighty managed to knit; the others could do nothing, and one blind man of fifty was, in addition, married to an "unable" woman of ninety-six. Such discrepancies of age between partners point to marriage as a strategy for survival. Another blind man in his fifties had a fatherless child of twelve to lead him about, and there were other "symbiotic" relationships of this kind. ${ }^{17}$

Although generically described in many cases, the sick poor of the census obvi-

\footnotetext{
${ }^{15}$ Pound, op. cit., note 13 above, pp. 13-15, 66, App. I, 15-17, App. III. Unemployment of males, by contrast, stood at one-third: ibid., p.16.

${ }^{16}$ The English population estimates derive from E. A.Wrigley and R. S. Schofield, The population history of England 1541-1871: a reconstruction, London, E. Arnold, 1981, p. 528.

${ }^{17}$ Pound, op. cit. note 13 above, pp. 60, 62, 70, 73, 79, 33, 29, 66, and passim. See also, M. Pelling, 'Old people and poverty in early modern town', Bull. Soc. soc. Hist. Med., 1984, 34: 42-47.
} 


\section{Healing the sick poor}

ously suffered from conditions appreciable by inspection. The information was evidently gathered by house-to-house visitation. Many conditions based primarily on the individual's perceptions of himself (e.g., colic) did not apparently threaten either his neighbours or his own capacity to work and were ignored by the city's inspectors. No great differentiation in diagnosis was required. The Norwich census is particularly valuable, however, in indicating a range of acute and chronic conditions, many of which, on the basis both of the annotations to the census and of their actual proceedings, the Norwich authorities would have regarded as amenable to treatment or to improvement (however temporary) in the necessaries of life. ${ }^{18}$ Blindness is a case in point; although to be blind was virtually to be "unable", the city authorities were at the same time ready to support the extensive (and apparently successful) activities of such peripatetic oculists as Richard Banister. ${ }^{19}$ Similarly, the possibility of medical poor relief was extended by Norwich to all ages from four to eighty, a reflection of the wider age range of those thought capable of contributing directly to their own support.

The sick poor identified in 1570 were not, therefore, regarded fatalistically, or abandoned to any mere rhetoric of prevention. The 1570s scheme provided that the proctors or keepers of the city's lazarhouses, as well as poor women, should receive into their houses "the diseased, including the leprous"; and from this time onwards, the city employed significant numbers of practitioners to treat the poor. ${ }^{20} \mathrm{~A}$ few people mentioned in the census can be identified with those subsequently provided with medical relief. Among those treated at city expense after 1570 there were, as the census details would lead one to expect, as many women as men, but, by contrast, a much higher proportion of children or young people. This more accurately reflects the age structure of the population as a whole, as well as the poor scheme's concern for the physical and moral degeneration of children, a concern which parallels that expressed in London's policies, and in humanist attitudes to the poor. Even very young children were able to help their parents (or the people with whom they lived); sick children could neither learn nor become apprentices; it was therefore worthwhile for the city to pay for them to be treated. The census provides clear evidence that children worked and contributed significantly to the support of the household.

\section{II}

At this time, Norwich had a ratio of practitioners to population of around 1:200. ${ }^{21}$ Of this large and disparate group no less than one-eighth, at a minimum, were

\footnotetext{
${ }^{18}$ Although it cannot be dealt with here, it is important to note the part played in poor relief in Norwich and elsewhere by extra or temporary payments made to the poor in time of sickness, i.e. "sickness" as opposed to "medical" benefit: see Levy, op. cit. note 1 above, pp. 45-50.

${ }^{19}$ See DNB; R. Banister, Treatise of one hundred and thirteene diseases of the eyes, London, Felix Kyngston for Thomas Man, 1622, sigs. [d7v-d8r]; NRO, Mayor's Court Proceedings no. 15, 1615-24, fol. 303.

${ }^{20}$ The chief sources are the 'Mayor's book of the poor', I and II, and the Mayor's Court Proceedings (NRO). Transcripts of the former and associated documents by J. M. Dixon are deposited in the Local History section of the Central Library, Norwich. See also J. M. Dixon, 'Poor relief in Norwich', University of Leeds MA dissertation, 1927.

${ }^{21}$ See Pelling and Webster, op. cit., note 1 above, pp. 207-226, esp. pp. 225-226; see p. 208, note 83 for sources. 270 is a revised total.
} 


\section{Margaret Pelling}

employed at some time by the city. More than a third of these were women, including a woman surgeon and women keepers of the lazarhouses or poorhouses who are known to have taken on cures. ${ }^{22}$ The remaining two-thirds were chiefly barber-surgeons, surgeons, and bonesetters, with a sprinkling of apothecaries, physician-surgeons, and recruits to medicine from other trades. Although the proportion of women is high, the city effectively chose representatives of the full range of available practitioners, roughly in the proportions in which they were present, from the more to the less formally qualified.

The city's choice was not affected by any of the factors conventionally regarded as restricting or regulating medical practice in this period, such as being free of the city, native-born, or licensed to practise. Some of those chosen were freemen, some were not, although this could vary in other towns where the freedom was more important for all trades. Similarly, from Norwich's point of view, standing in the barber-surgeons' company made no difference, and the city also felt able to employ aliens, in particular "Dutchmen". Since weakness of restriction on English-born immigrants to Norwich was a feature of the economic life of the town, it would be surprising if the city had favoured indigenous practitioners in particular. ${ }^{23}$ Of the whole group of thirty-four practitioners employed by the city, only five show any signs of contact with the ecclesiastical licensing system, and there is no evidence that this affected their employment. This also is hardly surprising, since ecclesiastical licensing had little impact on Norwich medical practitioners as a whole.

That the city did not more often choose the same practitioner from the wide range of available personnel was a reflection, circumstances apart, partly of a mode of practice in which fewer patients were taken on for longer periods of time, and partly of the commercial system under which practitioners were employed. With a few important exceptions, Norwich did not pay stipends to practitioners who treated the poor, but instead came to a separate agreement for each case. Like the individual, the city exercised consumer choice, being one party in a conditional contract in which the practitioner was usually paid something on account and a balance when the contract was fulfilled. Conditional contracts were the rule, rather than the exception as is usually suggested; they are not peculiar to Norwich, and continued well into the seventeenth century. The advantage to the practitioner of this style of agreement was that he took only those cases where he estimated he stood a definite chance of success, or at least of an agreed level of success. This principle was enshrined in barber-surgeons' ordinances, which prohibited the taking-on of dangerous cures until the case had been seen by those best able to assess the risks of the contract, to the practitioner as well as to the patient. ${ }^{24}$ The Elizabethan class of incurables thus has some contact with the contemporary systems of medicine and law, rather than being a vague or merely fatalistic description. A main charge of deceit in practitioners could consequently lie in their taking in hand diseases which they knew to be incurable, as well as in their not attending their failures. ${ }^{25}$ In certain cases a

${ }^{22}$ Midwives have been excluded from this calculation.

${ }^{23}$ This point is developed in M. Pelling, 'Occupational diversity: barbersurgeons and the trades of Norwich, 1550-1640', Bull. Hist. Med., 1982, 56: 484-511.

${ }^{24}$ For ordinances see sources given in ibid., p. 492, notes 28 and 29. 


\section{Healing the sick poor}

charge of witchcraft could arise from a claim to cure an incurable disease.$^{26}$ Most proceedings against practitioners fit much more readily into the framework of breakdown of agreed contracts, than into the modern category of malpractice suits.

Regardless of formal provisions, however, the number, diversity, and competitiveness of practitioners ensured that risks continued to be taken. With respect to poor patients at least, there was often an element in the contract guaranteeing that the practitioner would "keep the patient whole" for the rest of his or her life. This is best seen as referring, not to drastically different life expectancies or to an exaggerated faith on the part of the practitioners in their own powers, but rather to a kind of speculation involving a transfer of responsibility. Should the patient in question be found again in the same condition, the city would regard the practitioner as liable to treat him or her under the terms of the original agreement.

The city authorities may therefore be regarded as in a sense putting out to tender, and it should not be supposed, because practitioners were sometimes imported from Yarmouth, or cases sent to Coventry, that there must have been no practitioners close by. The prevalence of this type of contractual agreement helps to explain why the few practitioners whom the city attempted to employ on a retainer basis were specialists. The special skills of the latter gave them a bargaining advantage. "Tendering" continued to be a feature of medical life into the twentieth century, but was increasingly excluded from "private" practice. In the eighteenth century, "contracts" appear more like retainers, and are seen as peculiar to the poor-law context; expensive or ubiquitous conditions such as bonesetting or midwifery continued to require special arrangements. ${ }^{27}$

More investigation is required before it can be decided whether the town physicians and surgeons employed at Chester in 1574, Ipswich in about 1585, Newcastle from 1599, and Barnstaple in 1629, were of this type or were closer to the continental model of the state-salaried medical and public health officer. Certainly, in all these towns there is evidence of the presence of a large number of other practitioners. In the Chester example, there was reference to ulcers and wounds, but also to sicknesses and diseases in general; Barnstaple, characteristically of a period in which more was being expected of the professions, described its physician as "learned". These towns paid higher fees than Norwich; Ipswich in allowing $£ 30$ per annum, Newcastle in rising to $£ 40$ per annum in 1632 , came closest to Brinklow's idea of stipend. It may be noted that money had been bequeathed from before 1550 to pay stipends to physicians to treat the poor of specified parishes, although such charity was principally confined to London. ${ }^{28}$

\footnotetext{
${ }^{25}$ See Banister's criticisms of Henry Blackburne: A. Sorsby, 'Richard Banister and the beginnings of English ophthalmology', in E. A. Underwood (editor), Science, medicine and history: essays ... in honour of Charles Singer, 2 vols., London, Oxford University Press, 1953, vol. 2, p.52.

${ }^{2} \mathrm{P}$. Richards, The medieval leper and his northern heirs, Cambridge/Totowa, N.J., D. S. Brewer/Rowman \& Littlefield, 1977, pp.71-72.

${ }^{27}$ E. Melling (editor), Kentish sources: IV. The poor, Maidstone, Kent County Council, 1964, p. 135. Emmison (1933), op. cit., note 1 above, p. 76, thus finds that contracts with medical practitioners appear at an earlier date than contracts with workhouse keepers.

${ }^{28}$ R. H. Morris, Chester in the Plantagenet and Tudor reigns, Chester, [for the author], [1895], p. 357; Pelling and Webster, op. cit., note 1 above, p. 228; Leonard, op. cit., note 1 above, pp. 201-202; C. H. Mayo (editor), The municipal records of the borough of Dorchester, Dorset, Exeter, 1908, p. 518. Cf. C.M.
} 


\section{Margaret Pelling}

Norwich's most successful arrangement of the regular kind was with bonesetters. Richard Durrant, the best-known example, was probably an immigrant to Norwich, and first came to the city's notice during the poor scheme of the 1570s. Paid at first on the usual contract basis, Durrant impressed by his skill and for about ten years was paid quarterly first $£ 4$ and then $£ 8$ per annum, as well as a house in the city rent-free. Durrant's connexion with the city outlasted the main provisions of the poor scheme. By 1589, just after his period of employment by the city, Durrant was a householder, warden of the barber-surgeons' company, and engaged in an activity common among prosperous barber-surgeons, that of standing surety to licences relating to the retailing of drink. While on the city's payroll, Durrant was subject to one restriction, that of residing in Norwich. In addition to being skilful, Durrant was not grasping: he was rewarded in 1574 for healing poor people without asking for payment. After his death, the city retained the services of Phineas Reve on the same terms. This type of commitment, like so many other aspects of Norwich's medical relief system, had diminished by the mid-1630s: the city's employment of bonesetters continued, but on the old contract basis, and it was on the same basis that one of Durrant's bonesetter descendants was paid in the $1660 \mathrm{s.}^{29}$

After their successful experience with Durrant, the city attempted a similar arrangement in respect of another speciality, lithotomy, particularly important because of the high incidence of stone in East Anglia. These patients were most often small boys, as young as four years; it was at this age that the operation stood the best chance of success, but the acuteness of their suffering was perhaps another reason why sums as high as $£ 10$ were paid for them to be operated upon. ${ }^{30}$ Lithotomists' contracts were unusual in often including a clause guaranteeing the whole contract even if the child died. Sometimes the operator was required to produce the stone in evidence. As is more familiar from later periods of poor law administration, the city's retention of Miles Mayhew, surgeon, freeman, and officebearer in the barber-surgeons' company, at an annual fee, was an attempt to reduce the high overall costs of these cases. A search for less drastic and therefore cheaper methods of surgical treatment probably lies behind the interest taken in the achievement of the Norwich surgeon John Hobart, who, in 1593, was reported as having removed a very large stone from a woman without cutting. ${ }^{31}$ Some indication of the city's motives may be gathered from a reference by Kent authorities in 1598 to a boy of eleven "so grevously torment with the stone that he ys not able to work but needeth dayly relief".32

Cipolla, Public health and the medical profession in the renaissance, Cambridge University Press, 1976. Webster (1975), op. cit., note 1 above, pp. 256-264. W. K. Jordan, Philanthropy in England 1480-1660, London, Allen \& Unwin, 1959, p. 272. Norwich's fees to specialists were comparable with those paid to bonesetters and others by London hospitals; the stipends paid by other towns were higher than the salaries of St Bartholomew's surgeons: G. Whitteridge and V. Stokes, A brief history of the hospital of Saint Bartholomew, London, the Governors, 1961, p. 23.

${ }^{29}$ Pelling and Webster, op. cit., note 1 above, p. 217; NRO, Case 18, shelf d, Clavers' [Hamper] Accounts 1550-1601, see 1574-87; Case 17, shelf d, Book of innkeepers and tipplers 1580-90, fol. 11.

${ }^{30}$ Pelling and Webster, op. cit., note 1 above, p. 219 and note 92.

${ }^{31}$ Williams, op. cit., note 12 above, p. 1181 . This case may mark a shift from the Celsian to the Marian operation, which was based on observations on women, but which was, however, more elaborate: H. S. Shelley, 'Cutting for the stone', J. Hist. Med., 1958, 13: 52-54.

${ }^{32}$ Melling, op. cit., note 27 above, p.13. 


\section{Healing the sick poor}

Initially, the city arranged a contract with Mayhew for one patient for $£ 3$, subject to his being granted an annual fee of $£ 10$ at the next Assembly, in which case the contract was to be absorbed. Mayhew was so retained, but he continued to be paid totals of $£ 3$ and $£ 4$ for separate cases. By 1618 , the city was making these additional contracts dependent upon the patient's survival; it was then put in writing that Mayhew was to take for them what the court decided; and finally, Mayhew's fee was reduced to $£ 5$ a year. By 1621, matters had reached breaking point and it was resolved not to pay Mayhew his stipend because he refused to do anything for the poor and had demanded $£ 10$ for a single cure of a child. ${ }^{33}$ This, if the child achieved adulthood, would, according to one estimate, be enough for him to live on for four to five years. ${ }^{34}$ Mayhew's original agreement with the city clearly resembled the Chester arrangement in which the surgeon was to treat those living on alms for nothing (in which case they would not be recorded), and to cure others among the poor "for such reasonable sum and sums of money and other considerations as shalbe appointed by the mayor". The Chester surgeon would receive for the almspeople some payment in kind, referred to as "the stuff being ordinary". The "other considerations" at the disposal of Chester's mayor included the freedom. Dispensation was a convenient (and often invisible) method of paying for such services: Norwich lazarhouse keepers were excused part of their rent, and there is evidence that in Norwich a practitioner who took responsibility for one of the sick poor, which included an undertaking that the patient would not thereafter be chargeable to the city, would be exempted from paying the poor rate, at least for a time. ${ }^{35}$ It is important to stress that financial records do not necessarily give the whole picture. Payment, even by municipalities, was often invisible, or in kind, as is better known in the context of rural practice.

With respect to the cost of an individual contract, that proportion which the Norwich parish did not pay (from the poor-rate, or by special collection) usually came from a special account called the hanaper or hamper. Money went into this account from regular city sources of income, from fines relating to guild misdemeanours, trades offences, keeping alehouses, playing illegal games, putting on plays, and ill rule generally. By this time, guild finances and organization in Norwich probably allowed little scope for support of members of an occupation, although such sources were occasionally tapped: Tailors' Hall was asked in 1620 to contribute towards the cure of a tailor's widow being treated at some expense at $\mathbf{S t}$ Bennet's gates lazarhouse. ${ }^{36}$

The stipend of Richard Durrant, however, derived from the revenues of Norwich's main "hospital", known as St Giles's, or the Great Hospital, or God's house. This institution, substantially endowed and physically enduring, is of the kind often placed

${ }^{33}$ NRO: Mayor's Court Proceedings no. 15, 1615-24, fols. 76v, 77v, 186v, 211v, 364r, 384v; Press E, case 18, shelf a, Chamberlain's Accounts, 1603-25, passim 1617-22. Mayhew first came to the city's notice as a medical practitioner-in 1610: Mayor's Court Proceedings no. 14, 1603-15, fol. 276v.

${ }^{34}$ W. K. Jordan, The charities of rural England 1480-1660, London, Allen \& Unwin, 1961, p. 11. 62.

${ }^{35}$ Morris, op. cit., note 28 above, pp. 201-202; NRO, Mayor's Court Proceedings no. 15, 1615-24, fol.

${ }^{36}$ Hudson and Tingey, op. cit., note 14 above, vol. 2, pp. xcviii, ci; NRO, Mayor's Court Proceedings no. 15, 1615-24, fols. 320r, 324r. Expenditure on medical relief from the Hamper (including Durrant's annual payments) was also continuous over the period when the Bridewell Accounts and the Mayor's Books of the Poor record some similar outlays. Some expensive ad hoc cases were part paid for out of the revenues of the Great Hospital. 


\section{Margaret Pelling}

in the foreground of the historical picture. ${ }^{37}$ In the present context, however, it has no great importance. When badly run, it catered for the pensioners of aldermen; when well run, for those past work. During a reform period around 1620, better provision was made for those inmates who fell ill; but not long after, inmates were being expelled specifically because they were "grievously diseased" or infirm. One man, terminally ill, was sent home, although he continued to receive the "allowance of the House" for his relief; another sick inmate, significantly, was sent to St Bennet's lazarhouse.$^{38}$ God's house, like the later voluntary hospitals, undoubtedly rejected "infectious" cases. A "place of ministering physic and surgery to the poor in the Hospital" persisted into the $1630 \mathrm{~s}$, and tended to be held by aldermanic apothecaries. ${ }^{39}$ This office, at $£ 4$ per annum, was worth rather less (allowing for inflation) than the fee paid to Durrant when he was first appointed.

\section{III}

Norwich did not require a single institutional framework for the provision of medical care. With respect to the poor in institutions, care was, in practice, provided where it was needed, whether by inmates of the gaol, Bridewell, or the old "Normanspitel", which was for women. Although even the Hospital was to some extent (largely in the negative sense, by expulsion, or the threat of it) used to control unruliness, it was in the lazarhouses that the regulation of health was positively and effectively combined with the regulation of behaviour. Like Sir Thomas More's utopian hospitals, and for similar reasons, lazarhouses were on the outskirts of the city, at the main points of entry. The best known and longest-lived of these comparatively fragile medieval and late medieval institutions was the Lock in Southwark. The last of London's ten lazarhouses was founded as late as 1473. After 1547, when St Bartholomew's Hospital was granted by the crown to the city of London, five or six of these houses took on a more visible life. Their proper inmates were described by William Harvey in 1633 as the incurable, the infectious, and the scandalous. St Bartholomew's surgeons operated there, and dismemberments or dissections were carried out in the later sixteenth century, apparently by the keepers. Claims were made by some keepers as to a high turnover of patients and cures of difficult cases, but the houses also had an explicit role in suppressing begging and idleness, and, more covertly, served as a repository for decayed servants of patrons or of the supervising institutions. ${ }^{40}$

\footnotetext{
${ }^{37}$ C. B. Jewson, History of the Great Hospital, Norwich, 2nd ed., Norwich, for the Hospital, 1966; Jordan, op. cit., note 34 above, pp. 115-116.

${ }^{38}$ NRO, Mayor's Court Proceedings no. 15, 1615-24, fols. 263v, 272r, 387r; W. L. Sachse (editor), Minutes of the Norwich Court of Mayoralty 1630-1631, Norf. Rec. Soc., vol. 15, 1942, pp. 143, 172. ${ }^{39}$ Pelling and Webster, op. cit., note 1 above, p. 221.

${ }^{40}$ London's lazarhouses are exhaustively surveyed by M. B. Honeybourne, 'The leper hospitals of the London area: with an appendix on some other medieval hospitals of Middlesex', Trans. Lond. \& Middx. Archaeol. Soc., 1963, 21: 1-61. Thomas More, 'Utopia', in Famous utopias, New York, Tudor Publishing Co., [n.d.], p.175. On lazarhouses in general see J. Y. Simpson, 'Antiquarian notices of leprosy and leper hospitals in Scotland and England', Edinb. med. surg. J., 1841, 56: 301-330; ibid., 1842, 57: 121-56, 394-429; G. Newman, 'On the history of the decline . . . of leprosy . . . in the British Islands', Leprosy prize essays, New Sydenham Soc., vol. 157, 1895, pp. 1-150 (houses listed in Appendix); C. Creighton, $A$ history of epidemics in Britain, 2nd ed. (1st ed., 1894,) 2 vols., London, Frank Cass, 1965, vol. 1, chap. II; Richards, op. cit., note 26 above.
} 


\section{Healing the sick poor}

The officer in charge of a lazarhouse was expected to be resident and to attend the poor in his own person. He was called variously the governor, keeper, or guider of the poor or of the hospital, and his grant was normally for life. ${ }^{41}$ Although not of the same magnitude or dignity as masterships of hospitals or almshouses, the keeperships of lazarhouses could represent a modest sinecure or speculation. Families established interests in them, and a husband could transfer his part in them to his widow; the guidership could also be disposed of as an asset for short periods. In London, the keeper was usually paid a stipend and expenses for his inmates, although in difficult times the stipend could disappear. A keepership could also be given to buy off a petitioner who was poor or disabled himself, especially through war service. As we shall see, the Norwich keepers ranged from the poor to the prosperous. Even lazarhouses unendowed with land, being just outside the city and on main roads entering it, were well-placed for an activity much favoured by medical practitioners at all levels, the sale of food and especially of drink. London and Norwich lazarhouse keepers were prohibited from keeping alehouses and fined for unlicensed tippling. ${ }^{12}$

The Norwich lazarhouses differed from the London examples in not being connected, even administratively, with the city's refounded hospital. Although essentially independent, their activities were increasingly supervised by the magistracy of the mayor's court, a more direct method of centralized control. A more major difference is that it is easier to suppose a significant role for such places in the care and treatment of the poor at this period in the case of King's Lynn, which had five houses, or Great Yarmouth, which had two, or Norwich, which had at least five, than it is in the case of London, which then had the same number or fewer than Norwich for a population more than ten times as large. ${ }^{43}$ This is not to say that the houses were imposing structures, like Thomas More's hospitals, which were envisaged as large enough to be taken for small towns. Norwich's lazarhouses probably followed one of the common patterns for leper hospitals in consisting of one solid structure at most combined with a number of small cottages. They were conveniently placed on the north-west boundaries of the city, close to the parishes which, in the late sixteenth century, were both densely populated and poor.4

Another difference between London and Norwich was that in Norwich it was the rule rather than the exception for a husband and wife to act as joint keepers. In 1618, when part of an aldermanic legacy was distributed to the keepers, three of the five recipients were women..$^{45}$ The role of the women increased as the houses were more extensively used by the city, and very often it was the wife rather than the husband

\footnotetext{
${ }^{41}$ Traditionally, funds were collected for lazarhouses in the outside world by travelling proctors or foregoers, who were often elected or selected from among the house's inmates. As the functions of proctors were eroded or discredited, the distinction between guiders, proctors, and keepers increasingly disappeared. "Keeper" was most commonly used by the Norwich authorities. F. Cohen, 'On the word proctor. .', Archaeologia, 1817, 18: 9-11; Hudson and Tingey, op. cit., note 14 above, vol. 2, p.169; NRO, Mayor's Court Proceedings no. 13, 1595-1603, pp. $29^{*}, 299$.

${ }^{42}$ Honeybourne, op. cit., note 40 above, p. 33; NRO, [Hamper] Accounts 1550-1601, fol. 132; W. L. Sachse (editor), Minutes of the Norwich Court of Mayoralty 1632-1635, Norf. Rec. Soc., vol. 36, 1967, p. 53. For the connexions between medical practitioners and the food and drink trades see Pelling, op. cit., note 23 above.

${ }^{43}$ Victoria County History, Norfolk, vol. 2, pp. 453, 442.

"Pound, op. cit., note 13 above, pp. 10-11.

${ }^{45}$ NRO, Mayor's Court Proceedings no. 15, 1615-24, fols. 186v-190r.
} 


\section{Margaret Pelling}

who was employed by the city to cure the sick poor. On the deaths of their husbands, the women often carried on alone as keepers. No distinction was made between men and women as to the type of cure, the fee paid, or the sex and age of their patients.

The role of women, and other aspects of the activities of Norwich keepers, can be illustrated by specific examples. Lawrence Wright is designated a physician in Raach's directory of provincial practitioners on the strength of his undertaking cases for the city, including one of "thistely", the contract being priced, appropriately to the difficulty of the condition, at $£ 3$. Wright was, in fact, a barber or barber-surgeon, a freeman, and officebearer in the barber-surgeons' company.$^{46}$ During the 1590 s, he had indentured the unusually large number of six apprentices, one of them in conjunction with his first wife Margaret, herself the daughter of a barber, William Pickering, who also employed large numbers of apprentices. Wright and his father-in-law are typical of barber-surgeons who may have been engaged in manufacture as well as barbering. ${ }^{47} \mathrm{~A}$ second phase of Wright's life began when he married as his second wife Alice Edwards, whose first husband, William Edwards, had rented St Bennet's gates lazarhouse and taken charge of poor diseased people for at least twenty-five years up to $1614 .^{48}$ On their marriage, Alice and Lawrence Wright became joint keepers and were paid individually by the city for undertaking cures. Between June 1615 and June 1616, Lawrence was entrusted with a new medical case almost every month, his contracts ranging between $£ 3$ and $4 s$, for conditions including lameness of both legs and a sore on the back. Wright's contracts varied in amount with the length of time for which he was to keep the patient, but also according to the severity of the condition, since the cost of keeping was low compared with the cost of some treatments. ${ }^{49}$

That Wright had some reputation as a practitioner, and also took on patients on his own account, is indicated by such cases as Margaret Betts, who was sent to him for cure by her brother from Elsing, about ten miles from Norwich. The city was only concerned that, having been cured, she should now return to her work on a farm near Elsing. In his will, Wright specified bequests totalling in the long term over £350, rather more than the bonesetter Durrant. ${ }^{50}$ His widow Alice continued to act as keeper of St Bennet's, dealing over the two years following Lawrence's death with a range of serious medical cases, including two of the French pox, one of them involving a whole family. Her contracts were priced similarly to Lawrence's at sums

\footnotetext{
${ }^{46} \mathrm{~J} . \mathrm{H}$. Raach, A directory of English country physicians 1603-1643, London, Dawsons, 1962, p. 95. For the main sources used in compiling Wright's biography see Pelling and Webster, op. cit., note 1 above, p. 208, note 83. In the Mayor's Court Proceedings, Wright is often called Leonard rather than Lawrence but the two are identical. Full details are obtainable from the Biographical Index of Medical Practitioners, $c$. 1500-1720, and covering especially London and East Anglia, at the Wellcome Unit for the History of Medicine, University of Oxford.

${ }^{47}$ See Pelling, op. cit., note 23 above, pp. 498-501.

${ }^{48}$ The sources for Edwards are the Mayor's Court Proceedings, the Chamberlain's Accounts, and especially the [Hamper] Accounts (NRO). It was probably he who obtained a "protection to gather" from the Privy Council as one of the proctors of St Giles's gates lazarhouse in March 1579/80: Hist. MSS Comm., Salisbury, 1888, pt. 2, p. 246. For Alice Edwards/Wright, besides NRO, Mayor's Court Proceedings no. 15, 1615-24, see Lawrence Wright's will, PCC 95 Weldon (1617).

${ }^{49}$ For examples of Lawrence's contracts see NRO, Mayor's Court Proceedings no. 15, 1615-24, fols. 17 , $35,38,46,51,62$.

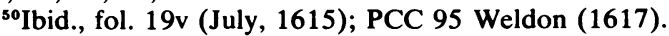


between 15s. and £3. At the same time, Alice took custodial cases and set them on work. She was succeeded by a couple called Stephenson, of whom the husband paid the rent of the lazarhouse, while the wife, Rose, already mentioned above, took on Alice's responsibilities. Rose's cases included scurvy and scald head, the latter being, as already indicated, a very common cause of concern, something of a woman's speciality, and one for which the London hospitals made at first female and then male appointments. $^{51}$ There is some evidence to suggest that scald head was related to venereal infection. ${ }^{32}$

To the full life history of the prosperous barber and keeper Wright, may be contrasted that of William Roberts, keeper of St Stephen's gates lazarhouse. The sum of Roberts' inventory at his death in 1601 was just under $£ 6$. In addition, however, to keeping a poor woman at the rate of $2 s .6 \mathrm{~d}$. a week, seemingly a low sum but still 150 per cent above what charitable bequests of the time thought sufficient for maintenance, Roberts was involved in contracts with the city for up to $£ 3$ for keeping the sick poor, including a woman and four children with the French disease. Roberts' chief moveable assets at his death included a cow worth $20 s$., wood worth $12 s .4 d$, and "certain instruments to draw a tooth with" valued at $12 d . .^{33}$

Just as conventional practitioners dealt in the future liability to illness of their patients, so the lazarhouse keepers accepted as part of a bargain the responsibility for future maintenance or keeping of a poor person in the event of their not being able to effect a cure. The keepers also speculated on their own behalf in the future liability represented by a poor person. Thus the amount agreed on between the keeper and a parish or individual for "keeping for life" was not necessarily a realistic estimate of the cost of a person's subsistence over an indefinite period but a more actuarial speculation involving an estimate of risks. The subjects of these speculations could be illegitimate infants, young children, and apprentices, as well as the adult poor.

All such transactions, involving as they did a transfer of responsibility, brought a kind of market flexibility to practices generally thought fairly rigid, like apprenticeship and settlement. This rigidity tended to reassert itself when an arrangement broke down, which was usually revealed when the poor person concerned was found begging at large by other authorities. Thus when, in 1630, Elizabeth Carter was punished for begging in Norwich and sent back to Cley in Norfolk, the inhabitants of Cley complained that they had made a bond as much as eleven years previously with Heath, the keeper of St Augustine's gates lazarhouse in Norwich, for him to keep Elizabeth for her life for the sum of $£ 413 s .4 d$. Even in the more rigid climate of the 1630 s, the justices of assize did not question the parish's right to transfer its responsibility, but dealt with the agreement as a private transaction: Cley's inhabitants might take remedy against Heath, but in the

\footnotetext{
${ }^{51}$ For Alice's contracts see e.g. NRO, Mayor's Court Proceedings no. 15, 1615-24, fols. 94v, 110v, 122r, 144v, 177r. For the Stephensons see ibid., e.g. fols. 253v, 257v, 295r; NRO, Press E, case 18, shelf a, Chamberlain's Accounts 1603-25, e.g. fol. 351; N. Moore, The history of St Bartholomew's Hospital, 2 vols., London, C. Arthur Pearson, 1918, vol. 2, pp. 732-733; K. F. Russell, 'John Browne, 1642-1702: a seventeenth-century surgeon. .', Bull. Hist. Med., 1959, 33: 395, note 5.

${ }^{52}$ This possibility is taken further in Pelling, 'Appearance and reality: barbersurgeons, the body, and disease', in L. Beier and R. Finlay (editors), The making of the metropolis (forthcoming).

${ }^{53}$ NRO: [Hamper] Accounts 1550-1601, fol. 137r; Mayor's Court Proceedings no. 13, 1595-1603, e.g. p. 358; NCC Inv. 17/91 (1601).
} 


\section{Margaret Pelling}

meantime the Norwich authorities had acted lawfully in expecting Cley to provide for Elizabeth. ${ }^{54}$

The lazarhouses thus performed a number of functions for their keepers and for the city. In particular, the city used them for the treatment of conditions that threatened the working capacity of the patient or, in the case of infectious conditions, of other poor as well. This quarantine function extended to any appearance of the person indicating communicable disease, by which could be meant an extensible corruption, as much as something more specific. Thus Thomas Gyles, keeper of Magdalen gates lazarhouse, was paid in $1598 / 9$ for receiving from Bridewell a "loathsome boy", who had been sent to Norwich on a passport because he had been born in Berstreet. ${ }^{55}$ As a massive corruption of the humours, showing itself very visibly on the surface of the body and especially the face, leprosy, which was declining, was closely related to the newer disease, the French pox or syphilis, and also to scurvy, leprosy being sometimes known as inveterate scurvy. ${ }^{56}$ In humoral pathology, the distinction between one disease and another was of degree rather than of kind. This did not mean that practitioners or even laymen failed to recognize specific conditions when strongly marked, but merely that they accepted the existence of intermediate states. ${ }^{57}$ Hence Susan Goose, a poor fatherless child, could be described as late as 1651 as "always sick, now leprous, and probably incurable". 58 Attention to any putrefactive condition in its early stages could thus prevent much worse forms of infectious decay.

The Norwich authorities were plainly more concerned about the "French disease" than any other. This was seen as affecting whole families, and constituted sufficient grounds for breaking indentures-something normally done only with great reluctance-and removing the apprentice if the master's family was known to have the disease. In 1600, the overseers and churchwardens were instructed, as part of a detailed programme for confining the city's charges for the poor to its statutory responsibilities, to inquire in their parishes if there were any persons who were sick and diseased and could do no work, what their infirmity was, "whether the French pox or some other contagious disease". ${ }^{59}$ Such instructions are reminiscent of the census of 1570 , but with a more specific emphasis. They are a significant indication of the importance of venereal disease in contemporary public as well as private life. Attention has rightly been drawn to plague as the most influential manifestation of disease in the late sixteenth and early seventeenth centuries, but it is arguable that the effects of syphilis were also a major-and more continuous-preoccupation over the same period. The incidence of venereal disease may have been extremely high, and each case could cast a shadow over the life of the individual for twenty years or

\footnotetext{
${ }^{54}$ Sachse, op. cit., note 38 above, p. 66; cf. idem, op. cit., note 42 above, pp. 32, 59-60, for a similar case, not so easily settled, involving the keepers of St Stephen's gates lazarhouse.

${ }^{55}$ NRO, Case 19, shelf c, Bridewell Accounts 1585-1686, 1598-9 [not foliated].

${ }^{56}$ The connexion between syphilis and leprosy was still being debated in the nineteenth century: Newman, op. cit., note 40 above, pp. 64-65.

${ }^{57}$ Paracelsus also held this view of syphilis: W. Pagel, Joan Baptista Van Helmont: reformer of science and medicine, Cambridge University Press, 1982, p. 153.

${ }^{58}$ James, op. cit., note. 9 above, p. 33.

${ }^{59}$ NRO: Mayor's Court Proceedings no. 13, 1595-1603, p. 325; Press D, case 16, shelf c, Assembly Minute Book no. 5, 1585-1613, fol. 244v.
} 


\section{Healing the sick poor}

more. Both economic and social relations were affected. Unlike plague, the French disease could repeatedly impose the burden both of moral misdemeanour and disqualification from active employment. ${ }^{60}$

Public danger of different kinds was thus a major criterion influencing the treatment of the sick poor, so that in many cases such treatment would be imposed rather than sought. Vagrants ran the risk of quarantine, confinement, or cure by local authorities. Literary sources also indicate that such risks, combined with that of forced labour, may have existed at an early date. To quote Crowley, "such as be sore, and will not be healed/Ought not in any case to be cherishèd". The term "eligibility" must therefore be used with caution. Nonetheless, Norwich's medical relief practices could attract: in 1617 they drew Simon Bushe, aged twelve, from ten miles away. He had been brought to Norwich on a cart by someone from his home village of Scottow who told him that he should have "meat enough in Norwich and a surgeon to heal him". The eligibility of a sick person for relief was usually sorted out at parish level, before the case was raised at the mayor's court. As might be expected, length of residence was the most important criterion, apart from public danger: at the time of the census, when systematic forced working was in contemplation, residence of more than two or three years was sufficient, but by the $1630 \mathrm{~s}$, the criterion of place of birth was more often applied. ${ }^{\text {B1 }}$

At the same time, the city was more concerned about consequential than immediate expenditure, and medical relief often came into the latter category. The lazarhouses, lying outside the city walls and to some extent independent of the city, provided an especially convenient transit station for disabled people whose place of origin was in dispute, such as the blind cripple Mary Ambree, who was kept at the Magdalen gates house for several weeks before being sent back to Newcastle. ${ }^{62} \mathrm{~A}$ lazarhouse was also an ideal compromise solution for people like maimed and diseased soldiers, to whom the city might hope to avoid paying a pension. ${ }^{63}$ In such cases, the city could pass on the problem by paying the lazarhouse keeper a lump sum. However, for other kinds of disabled poor, who were allegedly "settled" elsewhere and whose disability-dumbness, falling sickness-affected only themselves, without immobilizing them, Norwich often did nothing, and did not withhold the usual punishments either. "Distracted" and "mad" people not settled in Norwich were told to leave under threat of punishment, or carried out of town, a city employee being paid to effect this; some mad people, presumably out of their own control, were carried as far as their place of origin. Norwich's practices reveal why sturdy vagrants might have chosen particularly to counterfeit as "dummerers", bedlams, cripples, or sufferers from falling sickness. These conditions aroused a response from passers-by without involving the same risks of quarantine,

\footnotetext{
${ }^{\circ}$ See Pelling, op. cit., note 52 above.

${ }^{1}$ Robert Crowley, quoted in Tawney and Power, op. cit., note 8 above, vol. 3, p. 406; NRO, Mayor's Court Proceedings no. 15, 1615-24, fol. 117r.

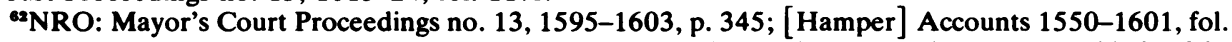
134. For a similar policy towards sick poor in transit see Webb, op. cit., note 1 above, pp. 75, 80, 85, 86 .

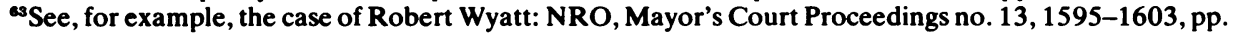
$128,155$.
} 


\section{Margaret Pelling}

confinement, and cure, even though such disabilities would not necessarily inhibit authorities from using the whip. ${ }^{64}$

The treatment of the insane tends to be taken as a sure test of contemporary attitudes. Norwich's disposition of its own lunatics varied. It maintained, at least after the setting up of the new Bridewell in 1585, a house for mad people supervised by the keeper of Bridewell. One of the inmates was a lunatic minister, Mr Kirby, who was in and out of gaol and Bridewell for two years in the 1590s at an average cost of three to four shillings weekly, before the city managed to arrange with the diocese a levy on the county ministers of $12 d$. a week to match the city's contribution. ${ }^{65}$ There is no evidence that Kirby or any other lunatic in Bridewell was ever treated medically at the city's expense, so that it might seem as if Norwich's attitude to lunacy was purely regulatory. Lunatics were placed in bridewells in other towns from an early period, and are found in a house of correction (also, however, used as a sickhouse) in rural Norfolk in the $1650 \mathrm{~s} .{ }^{66}$ In the light of this institutionalization of some lunatics, and the overlap of regulatory functions of the institutions involved, the later history of the poor insane becomes less remarkable. It was to some extent traditional for lepers and lunatics (as well as epileptics) to share an asylum, as all three were often excluded from other medieval foundations. Leperhouses sometimes evolved into lunatic asylums at a later date, when leprosy had all but vanished; the presence of lunatics in what were once leperhouses has suggested a similar static and isolated role in society for confirmed lunatics as for confirmed lepers, but the traditional association should be borne in mind. Moreover, the presence of lunatics in the Norwich lazarhouses may even suggest some hope of cure; and it seems unlikely that Norwich either failed to discriminate among lunatics or entirely lacked such practitioners as Widow Mercer of Chester, who, on the grounds of her experience of such diseases, was given charge of a poor woman who had fallen into a frenzy. ${ }^{67}$

By the early seventeenth century, then, Norwich's authorities had evolved a range of expedients and institutions to deal with the sick poor. How were these experienced by a poor person? Only sequences of events can be reconstructed. In October 1615, for example, two boys, Daniel Stephenson and Philip Emes, were both ordered to be healed and kept by Lawrence Wright for a year, for which Wright was to have 10s. with 10s. to follow. By the end of December, Stephenson had got on to the streets again, was punished, and sent back to Wright at St Bennet's gates. Wright's regime again proved inadequate, and Stephenson was this time subjected to the stricter conditions of Bridewell. By early 1617, he had been discharged, and placed,

\footnotetext{
${ }^{64}$ Ibid., no. 15, 1615-24, fols. 369r, 310r. Thomas Harman, Caveat for common cursitors vulgarely called vagabones [1567], ed. E. Viles and F. J. Furnivall, Early English Text Soc., Extra Ser. vol. 9, 1869, pp. 47-48, 51-59. The authorities in Salisbury refrained from punishing some, but not all, poor people who were sick, lunatic, weak, pregnant, crippled, or lame: see Slack, op. cit., note 1 above, pp. 21, 24, 30, 32, 35-37.

${ }^{65}$ NRO: [Hamper] Accounts 1550-1601, fols. 104, 105, 108; Mayor's Court Proceedings no. 13, 1595-1603, pp. 239, 250.

${ }^{6} \mathrm{~J}$. R. Chanter and T. Wainwright, Reprint of the Barnstaple records, 2 vols., Barnstaple, A. E. Barnes, 1900, vol. 1, p. 42; James, op. cit., note 9 above, p. 29.

${ }^{67}$ R. M. Clay, The medieval hospitals of England, London, Methuen, 1909, p. 32; Simpson, op. cit., note 40 above, p. 308; Morris, op. cit., note 28 above, pp. 370-371. M. Foucault, Madness and civilisation, trans. R. Howard, London, Tavistock Publications, 1971, pp. 3-7, 45.
} 


\section{Healing the sick poor}

according to the best intentions of the Statute of Artificers, as an apprentice in husbandry. Events for his co-sufferer Emes were more summary. At about the end of the year he spent with Wright, he was taken vagrant in the city, whipped and sent back to the city parish where he claimed to have been born.$^{68} \mathrm{~A}$ third poor child, Thomas Hemblinge, was only five or six when the city and his parish paid for him to go to Rose Stephenson of St Bennet's to be cured of a scald head. Four months later, Thomas was cured, and the city was threatening to have him sent to Bridewell if his father failed to keep him at home. When he was again found on the streets however, the city merely sent him back to his father. In early 1621 , about eighteen months after first coming to the city's notice, Thomas was among the first to be admitted to the new Children's Hospital, another example of the re-institutionalization characteristic of the early seventeenth century. When old enough, he, too, would have been apprenticed..$^{69}$

Similarly, the example of John Blackborne and his daughter shows both the combination of medical with other forms of relief, and the recurrent nature of the city's responsibilities. In 1595, Blackborne's daughter's eye was treated at a cost of $7 s$. 8d. by John Hobart, surgeon, freeman, householder, and officebearer in the barber-surgeons' company. Five years later, Hobart was paid a total of $£ 3$ for attending to John Blackborne's leg. A little later, William Edwards, the then keeper of St Bennet's, and a woman were paid 6s. for clothing Blackborne and his daughter, and Edwards was paid further for keeping the daughter. ${ }^{70}$

Norwich's interest in the lazarhouses became more pronounced in the sixteenth century, but was not new to the post-Reformation period. Municipal participation was not alien to medieval foundations, and institutions depending partly on the municipality often had a better chance of surviving over the Dissolution period than entirely ecclesiastical or even private foundations. St Giles's gates lazarhouse in Norwich was known variously as a "poor house" and "sick house" from around 1540 , but the city had had some stake in it since the early fourteenth century. Attempts by the city to control all the lazarhouses were made as early as the $1540 \mathrm{~s}$, when St Stephen's and St Bennet's, as well as St Giles's, were referred to as “sick houses", but such attempts were hampered by the crown's appropriation of keeperships and the continuance of church ownership of the land of the houses, which in some cases persisted well into the seventeenth century. Nonetheless, the city was using St Stephen's gates lazarhouse and its proctor for the custody of lame beggars as early as 1562, that is, before Norwich's main effort of poor law organization in the 1570s. St Bennet's gates house, also called the spital-cotes or cottages, was city property from 1584; its keepers paid rent to the city from the 1580 s, sometimes obtaining remission for taking in the city's poor. Of the five active houses, St Bennet's was most extensively used by the city for the care of the sick. ${ }^{11}$

\footnotetext{
${ }^{68}$ NRO, Mayor's Court Proceedings no. 15, 1615-24, fols. 38, 48, 114v, 89r.

${ }^{69}$ Ibid., fols. 253v, 272v, 315r, 328v.

${ }^{70}$ NRO, [Hamper] Accounts 1550-1601, fols. 103, 135-7, 139.

${ }^{71} \mathrm{~F}$. Blomefield, An essay towards a topographical history of the county of Norfolk, 11 vols., London, William Miller, 1805-10, vol. 4, pp. 166-168, 245, 408-409, 438, 460-461, 509; Clay, op. cit., note 67 above, pp. 235-236; NRO, Society of Genealogists' transcript of parish register of St Giles, Norwich, PD 192/142; Hudson and Tingey, op. cit., note 14 above, vol. 2, pp. xcix, 169-170. Apart from Blomefield, the main sources for the Norwich lazarhouses are the Mayor's Court Proceedings and the Chamberlain's
} 


\section{Margaret Pelling}

The city's increased use of the houses after 1600 , very evident in the activity of the Wrights and others in the $1610 \mathrm{~s}$, was matched by increasing investment. Reparations were made and the houses benefited from aldermanic bequests. In 1623, three prominent aldermanic benefactors settled St Stephen's on the city and this was shortly followed by the proxy acquisition of St Augustine's. St Augustine's is an example of a lazarhouse gradually coming under local control. Under the perhaps unusual circumstances of his being brother to Matthew Parker, who, as Archbishop of Canterbury, had already taken a conscientious interest in hospitals and almshouses, Thomas Parker, Mayor of Norwich, had joined with the Bishop of Norwich in 1568 in removing an unsatisfactory keeper of this lazarhouse. Although used as a kind of quarantine station by the city as early as 1580 , its chief proctor was then still acting for the settled inmates on the basis of a licence issued not locally but nationally. By 1591, the proctor was too poor to pay the fee for this kind of licence and the bishop and local magistrates stepped in with a substitute permission to enable one of the inmates to travel and beg on behalf of the sixteen people then living in the house. Twenty years later, Norwich's aldermen took over the lease. ${ }^{72}$

This increased investment, as well as the continuing need to prevent the poor of other areas taking up residence in the town in a period of economic slump, inspired a covenant drawn up in 1623/4 between the city and the keepers of the houses, which reserved the houses to the city's control, even with respect to the "settled inmates". Although not salaried, the keepers were not to take any poor into their houses without the consent of the mayor's court, and they were to "keep their bellgate" according to the rules prescribed by the court. The second article seems to refer to the means by which keepers or their agents were entitled to extract money from members of the public, a practice which continued on a local level long after more wide-ranging collection was restricted. Thus Rose Stephenson, keeper of St Bennet's, in return for keeping during his life and attempting the cure of Thomas Gurney of the outlying district of Trowse, was to have $£ 3$ in two stages, Gurney's bedding, and also to "have her bellwalk in the said town": that is, to collect money in a locality previously closed to her. ${ }^{73}$

The city's commitment to the houses in the 1620 s probably included the intention of finding a regular means of support alternative to the small annual "country benevolence" which each of the houses had received since before 1600. This contribution from the county rates may have been jeopardized as a result of the determination of the city to have the final word on all admissions. The financing of the houses was always problematic. Like many lazarhouses, the Norwich examples were largely without settled revenues, and money left them by will, as by the barber Thomas Fulke in 1593, was for immediate use. The "country benevolence" was

and [Hamper] Accounts (NRO). The Magdalen gates house is to be distinguished from the Magdalen Hospital or lazarhouse at Sprowston, of which part survives: R. Taylor, Index monasticus, London, for the author, 1821, pp. 56-58; G. A. Stephen, 'A Norman relic: the lazarhouse, Norwich', The Millgate Monthly, Nov. 1921: 102-107.

${ }^{72}$ Blomefield, op. cit. note 71, vol. 4, p. 408; John Strype, The life and acts of Matthew Parker, London, J. Wyat, 1711, p. 272; Clarke, op. cit., note 11 above, pp. 332-333; NRO, Mayor's Court Proceedings no. $15,1615-24$, fol. $511 \mathrm{r}$.

${ }^{73}$ Ibid., fols. $511 \mathrm{r}, 246 \mathrm{v}$. 


\section{Healing the sick poor}

similarly divided up and placed in the hands of the keepers, who, even after the covenant of $1623 / 4$, persisted in making independent agreements with parishes outside Norwich. ${ }^{74}$

The activity in the field of medical poor relief in the 1620 s seemed to presage a commitment to wholehearted municipal provision. Even the strong line taken with Mayhew, the lithotomist, in the early 1620 s, may be seen as part of a determination to bypass market conditions in favour of municipal control. The city seemed prepared to abandon the marginal advantages of being able to transfer responsibility to the lazarhouse keepers as independent agents. Over the next ten years, however, this trend, which was never completed, went into reverse, a process which may have begun with the plague of 1625 and the consequent escalation of the poor rate. By the early $1630 \mathrm{~s}$, there was evident disillusionment with the lazarhouses themselves, their lack of revenues, and the frequency with which their inmates were found begging in the streets. The city began to grudge expenditure on repairs, and went so far as to withhold from the keepers the regular contribution from the county outside Norwich, in the hope of forcing the keepers to pay off arrears of rent. During 1634, the city's "evidences" for all the lazarhouses were examined to see if any of them could be "otherwise employed"; and, by the end of that year, St Stephen's, the house settled on the city in 1623 , was voted to be disposed of out of city ownership. ${ }^{75}$

Even institutionally, however, there was a degree of long-term continuity in Norwich's medical relief system. In the early eighteenth century, St Augustine's was an "infirmary" for aged poor people past work, who were unfit for common workhouses. In 1814, the buildings were being used for the same purpose, the land being leased from the bishop, the buildings owned by the city, and the enterprise supported by the poor rates, a structure not dissimilar to that of the early seventeenth century, except in the last respect. Blomefield, the early historian of Norfolk, was under the impression that most of the lazarhouses, even St Stephen's, continued as sickhouses until around 1700. By the early nineteenth century, the Magdalen gates lazarhouse had changed from leperhouse to "almshouse", to workhouse, and finally to alehouse, the last being, as we have seen, not so far from the first as might be imagined. $^{76}$

\section{IV}

The 1570 s will rightly continue to be regarded as the most notable decade in the history of Norwich's attempts to deal with the problem of the poor. It has been assumed that little of this effort, which is seen by Pound as having been prompted by political events, survived beyond 1590 , owing to a combination of immigration leading to plague and decimation of the poor population concerned. ${ }^{77}$ Moreover, even in Norwich, as in Salisbury, systematic schemes for providing the poor with

\footnotetext{
${ }^{74}$ Thomas Fulke or Hooke, NRO, NCC 138 Clearke (1593). For a distribution of the "country benevolence" in 1599, see NRO, Mayor's Court Proceedings no. 13, 1595-1603, p. 367.

${ }^{75}$ Sachse, op. cit., note 42 above, pp. 13, 120, 183, 184.

${ }^{78}$ P. Browne, The history of Norwich, Norwich, [1814], pp. 159, 228, 237; Blomefield, op. cit., note 71 above, vol. 4 , p. 168.

${ }^{77}$ Pound, op. cit., note 7 above, pp. 149-150.
} 


\section{Margaret Pelling}

work proved difficult to sustain. It does not seem plausible, however, to assume that either the need or Norwich's initiatives to meet it were confined to the period before 1600. The elements of Norwich's approach that related to medical services show a remarkable persistence from before 1570 and a development into the $1620 \mathrm{~s}$ and beyond. The lazarhouses later assumed on a minor level some of the functions of work promotion and regulation which the poor scheme had originally intended for other institutions, and, like the latter, were notable for the role played by women. The great plague epidemics between 1580 and 1625 may have encouraged the increased use of scattered institutions which would prevent the concentration of contagious putrefaction, but, at the same time, the lazarhouses were never used as pesthouses and had "ordinary" rather than extraordinary functions, as they did in London.

As in Salisbury, the Norwich initiatives of the 1620s and their decline in the 1630s coincided with a period of economic crisis. The chronology of "challenge and collapse" described by Slack for Salisbury in these decades is very similar to that in Norwich. Some support is provided for the view of Slack and of Davis that the context for welfare reform is urban crisis, a "conjuncture of older problems of poverty with population growth and economic expansion". As in Salisbury, however, decline or collapse occurred just when the need was greatest. ${ }^{78}$ It is not possible, by contrast with Salisbury, to say much about the influence of religious and political factors on short-term events in Norwich. The aldermen most involved in the lazarhouses, for example, belonged to both puritan and royalist persuasions. The overall phenomenon of municipal interest in medical poor relief is probably of greater importance than any observable short-term fluctuations. Medical aid continued, even if only to prevent greater expenditure or increase in the numbers of the poor. Strong reactions continued to be aroused by individual cases. In spite of the events of the 1630s, aspects of Norwich's system, in particular the element of the ad hoc service by "general" medical practitioners, remained as stable as other aspects of administration.

The Norwich methods show that the presence of town physicians or officials on the continental model is not the only measure of public investment in medical care. Considerable expenditure was involved in the Norwich system, and a surprisingly high proportion of the city's substantial complement of practitioners was employed in treating the poor over an extended period. Norwich was not, like Marshall, primarily concerned with curing vagabonds of their diseases so that they could be employed on major public works like fortifications and harbours. The city was, however, acting on the local level on behalf of its own residents to limit the extent and expense of incapacity. Specialized services were attracted to the city for the poor's benefit. The lazarhouses represent an attempt to provide cost-effective short-term medical treatment and supervision for the potentially able poor, on a joint basis with the parishes (and, in a sense, with the keepers) but with the main responsibility resting on the city magistrates. For the city, there were obvious advantages of flexibility in the connexions of the houses with the functions of the parishes,

\footnotetext{
${ }^{78}$ Slack, op. cit., note 4 above, p. 192; N. Z. Davis, 'Poor relief, humanism and heresy', in idem, Society and culture in early modern France, London, Duckworth, 1975, p. 59.
} 


\section{Healing the sick poor}

bridewell, and other city institutions, and with other relevant practices supervised by the mayor's court such as apprenticeship. Equally flexible was the combination of ad hoc or piecework medical service which needed no institutional basis, and the diverse, unpretentious institutionalization represented by the lazarhouses.

This paper has been concerned to approach an important area of social policy from the viewpoint of practice rather than statements of intent. The case of Norwich shows that in practice the poor were not divided simply into "the impudent and the impotent". Categories other than the traditionally impotent could be included in those eligible for relief, and such relief involved a flexible attitude to institutionalization. City authorities could indeed seek to remodel the poor themselves, to borrow Slack's phrase, in a highly literal and physical sense. ${ }^{79}$ This task was too important to be left to private philanthropy or even to the parishes. London was not alone among English urban centres in seeing the connexions between different kinds of decay, and London was not the only city to centralize its response to these problems.

\section{ACKNOWLEDGEMENTS}

I should like to thank the Archivist and staff of the Norfolk Record Office for their assistance, and Ludmilla Jordanova, Mary Hilton, and especially Charles Webster for their comments on this paper. I am also grateful for comments made on versions given in Cambridge, Lancaster, and Melbourne.

${ }^{79}$ Slack, op. cit., note 4 above, p. 183. 